\title{
ПАТЕНТОВАНИЕ ЗА РУБЕЖОМ ОСНОВНЫЕ ВОПРОСЫ И МЕРЫ ПОДДЕРЖКИ
}

\author{
УДК347.77 Дьяченко О.Г., К.Х.Н., АО "Российский экспортный центр"
}

dyachenko@exportcenter.ru

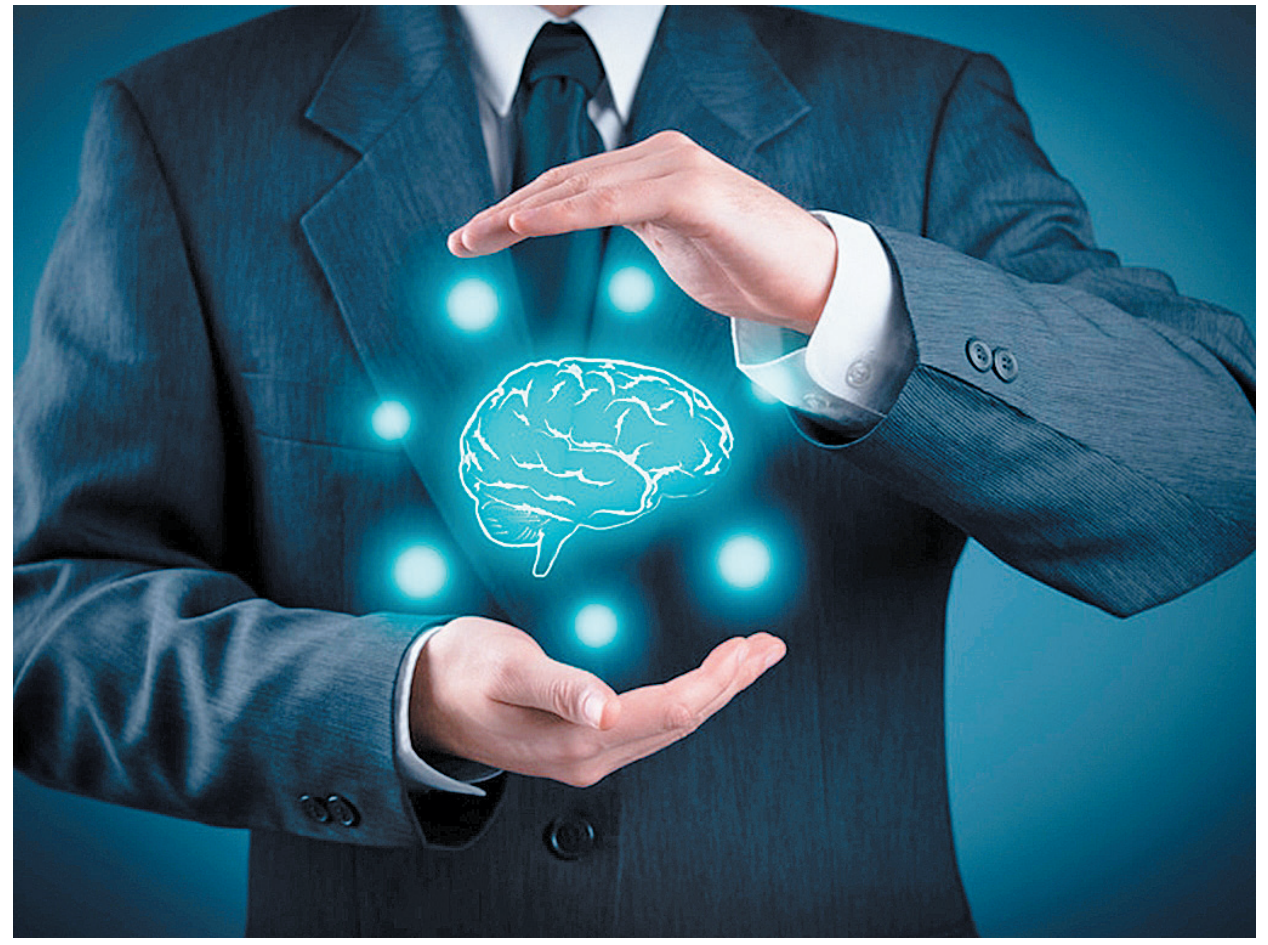

\begin{abstract}
Рассмотрены основные проблемы, с которыми сталкиваются российские компании при выходе на внешние рынки с высокотехнологичной продукцией. Описана последовательность действий при зарубежном патентовании. Приведены основные процедуры патентования за рубежом, их преимущества и недостатки. Рассмотрены меры поддержки российских компаний по вопросам интеллектуальной собственности со стороны ООО "Центр интеллектуальной собственности "Сколково" и АО "Российский экспортный центр".
\end{abstract}

Увеличение экспорта высокотехнологичной продукции является одним из важнейших условий устойчивого развития российской экономики. Вывод высокотехнологичной продукции на внешние рынки невозможен без обеспечения правовой охраны результатов интеллектуальной деятельности, лежащих в ее основе.

Итак, какие шаги в отношении зарубежного патентования необходимо предпринять компаниям, планирующим вывод своей продукции/технологии на внешние рынки?

Шаг 1: определить целесообразность зарубежного патентования.

Для этого следует ответить на следующие вопросы:

- планируется ли экспорт продукции, созданной на основе изобретения, права на которое принадлежат компании;
- планируется ли производство такой продукции за рубежом;

- предполагается ли заключение лицензионных соглашений с зарубежными партнерами, например, на передачу технологии производства продукции? Если хотя бы на один из поставленных вопросов дается утвердительный ответ, то патентование за рубежом как минимум целесообразно.

Шаг 2: подать заявку в Роспатент.

Порядок патентования за рубежом отечественных изобретений и полезных моделей, созданных в России, регламентируется статьей 1395 Гражданского кодекса Российской Федерации. Если изобретение или полезная модель произведены на территории 
Российской Федерации, то заявка на выдачу патента может быть подана в иностранном государстве или в международную организацию только по истечении 6 месяцев со дня подачи соответствующей заявки в Федеральную службу по интеллектуальной собственности (Роспатент). Однако это возможно при условии, что в указанный срок заявитель не получит уведомление о том, что в заявке содержатся сведения, составляющие государственную тайну. По просьбе заявителя срок проверки наличия в заявке сведений, составляющих государственную тайну, может быть сокращен [1].

Заявку в зарубежные национальные или региональные патентные ведомства, а также в международные организации необходимо подать в течение 12 месяцев с даты подачи заявки в России.

Шаг 3: выбрать страну/страны, где будет осуществляться правовая охрана изобретения.

При выборе таких стран следует обратить внимание на следующие ключевые моменты [2].

- В каких странах наиболее вероятна коммерциализация запатентованного продукта?

- Какие основные географические рынки у аналогичных продуктов?

- В каких странах действуют основные конкуренты?

- На территории какой страны будет изготавливаться продукт?

- Какие расходы связаны с патентованием в каждой стране? Какие средства есть у компании для этого?

- Насколько трудно обеспечить защиту патентных прав в каждой стране?

Шаг 4: выбрать процедуру патентной охраны за рубежом.

- Национальная процедура: заявка подается в национальное патентное ведомство каждой выбранной страны на требуемом языке с оплатой установленных пошлин. Делопроизводство, как правило, возможно только через местных представителей/патентных поверенных.

- Региональная процедура: заявка подается в региональное патентное ведомство, патентная охрана предоставляется на территории всех или нескольких стран региона.

- Международная процедура: подача международной заявки по Договору о патентной кооперации (РСТ) с последующим переходом на национальную фазу для получения патентов в выбранных странах.

Использование национальной процедуры целесообразно, если точно определены перспективы реализации изобретения в конкретных зарубежных стра- нах, количество этих стран небольшое (как правило, не более трех-пяти) и требуется максимально быстро получить правовую охрану в выбранных странах. Основные недостатки национальной процедуры:

- материалы заявок, описание и формула изобретения для подачи в патентное ведомство разных стран должны быть составлены по правилам этих стран и переведены на языки стран патентования;

- необходимо оплачивать услуги патентного поверенного в каждой стране патентования;

- большая часть расходов на патентование должна быть понесена в узкий временной промежуток (в общем случае, в течение 6 месяцев).

Региональная процедура может быть реализована путем подачи заявки в одно из существующих региональных ведомств: Европейское патентное ведомство, Евразийскую патентную организацию, Африканскую организацию интеллектуальной собственности, Африканскую региональную организацию промышленной собственности, Патентное ведомство Совета по сотрудничеству арабских государств Персидского залива. К основным преимуществам региональной процедуры можно отнести:

- снижение временных затрат и трудоемкости патентования;

- единый патент, действие которого распространяется на все страны региона;

- единые пошлины в одной валюте;

- единый язык делопроизводства;

- получение юридически более сильного патента, так как патент выдается только после проведения экспертизы по существу (в ряде стран региона может быть явочная система патентования);

- экономия расходов на патентование при необходимости получения патентной охраны изобретения более чем в 4 странах (для Европейского патентного ведомства).

К недостаткам региональной процедуры можно отнести необходимость оплаты большей части расходов в короткий промежуток времени (6 месяцев, как и в случае национальной процедуры), а также последующей валидации европейского патента в выбранных странах - участниках Европейской патентной конвенции.

Международная процедура реализуется в соответствии с Договором о патентной кооперации (РСТ), участниками которого в настоящее время являются 152 государства. Использование международной процедуры позволяет получить приоритет на изобретение одновременно в каждой из стран, подписавших Договор, путем подачи одной международной заявки, то есть подача 
Таблица 1. Объем высокотехнологичного экспорта в 2016 году [4].

\begin{tabular}{|l|c|c|c|}
\hline Страна & $\begin{array}{c}\text { Объем } \\
\text { экспорта, } \\
\text { млрд дол. }\end{array}$ & Место & $\begin{array}{r}\text { Процент об- } \\
\text { щего экспор- } \\
\text { та страны }\end{array}$ \\
\hline Китай & 496,0 & 1 & 25 \\
\hline Германия & 189,6 & 2 & 17 \\
\hline США & 153,2 & 3 & 20 \\
\hline Сингапур & 126,3 & 4 & 67 \\
\hline Республи- & 118,4 & 5 & 27 \\
\hline ка Корея & 103,8 & 6 & 27 \\
\hline Франция & 92,9 & 7 & 16 \\
\hline Япония & 6,6 & 28 & 11 \\
\hline Россия & & & \\
\hline
\end{tabular}

одной международной заявки приравнивается к подаче данной заявки во всех странах-участниках Договора. По сравнению с другими процедурами международная процедура обладает следующими преимуществами:

- невысокие первоначальные затраты: 2,5-3 тыс. долларов США с учетом услуг патентных поверенных;

- дополнительное время (как минимум 18 месяцев) для принятия решения о выборе стран патентования, оценки своих финансовых ресурсов, поиска инвестора и т.д.;

- отчет о международном поиске позволяет оценить перспективы дальнейшего патентования;

- публикация международной заявки является эффективным средством рекламы изобретения и поиска потенциальных лицензиатов, что дает возможность более ранней коммерциализации результатов интеллектуальной деятельности (РИД).

Исходя из указанных преимуществ, международная процедура является наиболее привлекательной для вузов, научных организаций и стартап-компаний.

Международную заявку часто ошибочно называют "международным патентом" и считают, что наличие такой заявки автоматически обеспечивает правовую охрану изобретения во всех странах - участниках Договора о патентной кооперации. Это, конечно, не так. Для того чтобы обеспечить такую охрану, необходимо перевести международную заявку на национальную фазу, то есть подать заявки в национальные/
Таблица 2. Полученные платежи за использование объектов интелиектуальной собственности в 2016 году [4].

\begin{tabular}{|l|c|c|}
\hline Страна & $\begin{array}{c}\text { Сумма платежей, } \\
\text { млрд дол. }\end{array}$ & Место \\
\hline США & 124,5 & 1 \\
\hline Япония & 39,0 & 2 \\
\hline Нидерланды & 38,9 & 3 \\
\hline Швейцария & 21,0 & 4 \\
\hline Германия & 17,6 & 5 \\
\hline Великобритания & 17,1 & 6 \\
\hline Франция & 15,5 & 7 \\
\hline Россия & 0,5 & 25 \\
\hline
\end{tabular}

региональные ведомства тех стран, где необходимо обеспечить правовую охрану изобретения.

Шаг 5: выбрать патентного поверенного.

При выборе патентного поверенного следует учитывать его квалификацию, репутацию, опыт работы, область специализации: патентное право или средства индивидуализации, владение техническими знаниями в конкретной области науки и техники, к которой относится изобретение. Подача заявки и ведение последующего делопроизводства для нерезидентов в большинстве стран осуществляется только через местного представителя/патентного поверенного. Поэтому российские заявители могут работать или напрямую с иностранными патентными поверенными в выбранных странах, или с российскими юридическими фирмами/патентными поверенными, которые имеют зарубежных партнеров в этих странах.

Но прежде чем начинать процедуру зарубежного патентования, необходимо удостовериться, насколько корректно закреплены за компанией права на РИд, планируемые к зарубежному патентованию: урегулированы ли взаимоотношения с авторами изобретения, с возможными соисполнителями НИОКР, для стартапкомпаний - с "материнскими" вузами/НИИ и т.д. Сделать это можно в рамках аудита интеллектуальной собственности. Невнимание со стороны руководителей организаций к вопросам закрепления прав на РИд может привести к оспариванию этих прав со стороны 
mwollob-estiv ЛАБТЕСТ

ЭАЕМЕНТНЫЙ И МОАЕКУАЯРНЫЙ АНААИЗ

СВОЙСТВА МАТЕРИАЛОВ

ЛАБТЕСТ
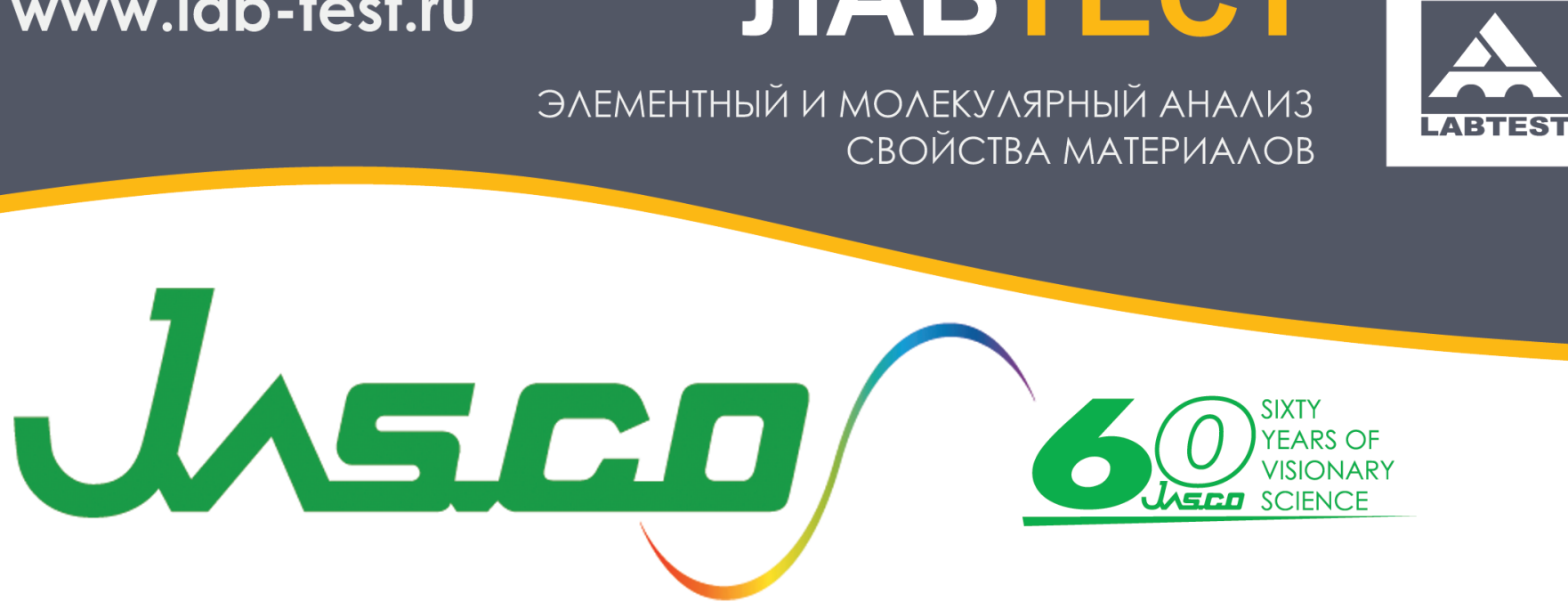
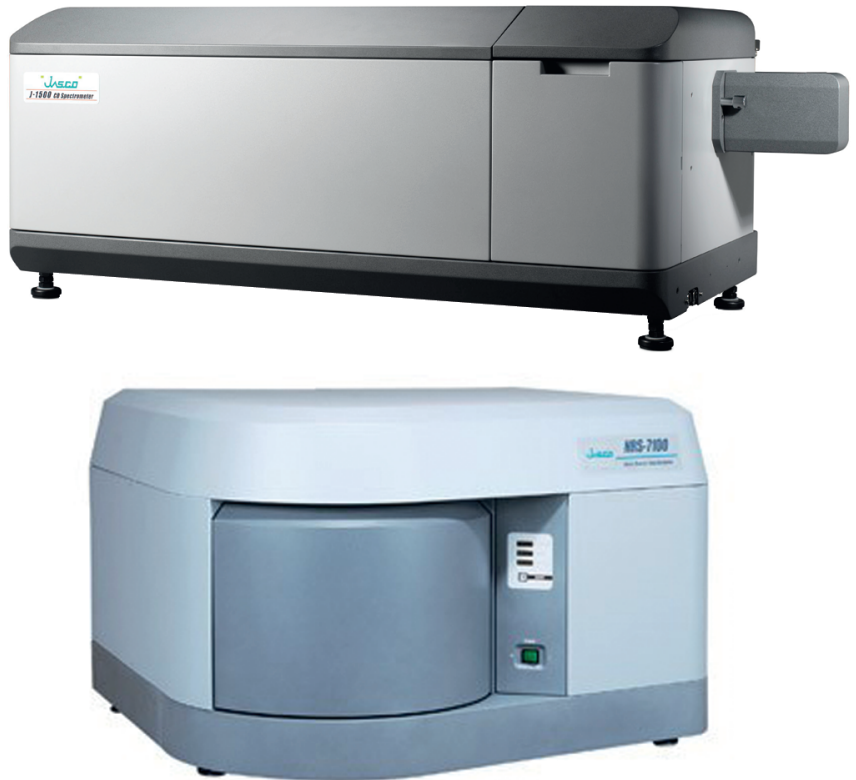

ИК-ФУРЬЕ-СПЕКТРОМЕТРЫ И МИКРОСКОПЫ

- Модели исследовательского класса и Аля рутинного анализа

- Гибкая конфигурация

- Полный набор приставок, вКлючая приставки комбинационного рассеяния и колебательного КА

\section{СПЕКТРОФОТОМЕТРЫ И} МИКРОСПЕКТРОФОТОМЕТРЫ

- УФ / ВИА / БИК

- Анализ объектов от 5 мкм

- Более 50 дополнительных приставок

\section{СПЕКТРОФАУОРИМЕТРЫ}

- Эмиссия $\triangle 01700$ нм

- Высокоскоростное сканирование

- Превосходная чувствительность

- Широчайший Аинамический Аиапазон

\section{СПЕКТРОМЕТРЫ КРУГОВОГО АИХРОИЗМА}

- Аиапазон Алин волн 163 - 2500 нм

- Регистрация сигналов: КА, ^А, ФАКА, МКА, Опт. п^ОтнОсть, \%Т, $\triangle О В$,

анизотропия фрлуоресценции, степень поляризации флуоресценции, интенсивность фмуоресценции, Т ${ }^{\circ} \mathrm{C}$

\section{ПОЛЯРИМЕТРЫ}

- Широкий выбор спектральных фрильтров и АополнитеАьных опций

\section{СПЕКТРОМЕТРЫ КОМБИНАЦИОННОГО РАССЕЯНИЯ}

- Спектральный Аиапазон 8,000 - $5 \mathrm{~cm}^{-1}$

- Встроенный микроскоп

- Высокое спектральное разрешение

- ОАновременное наблюдение образца, ^азерного пятна и апертурного изображения

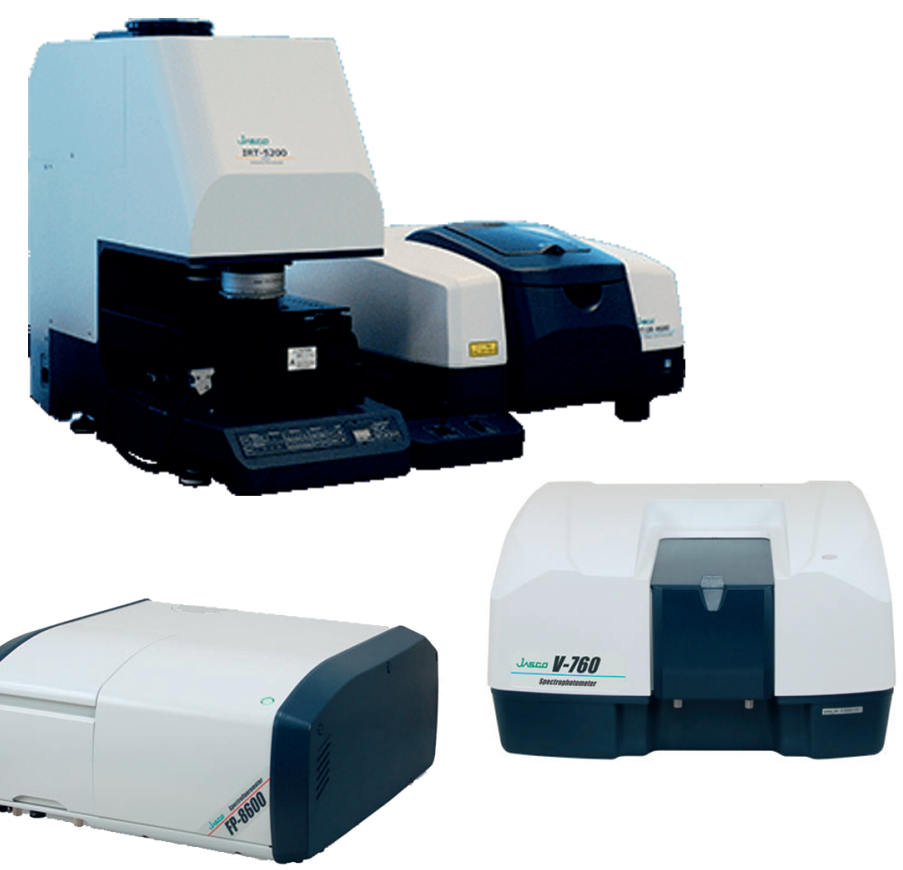




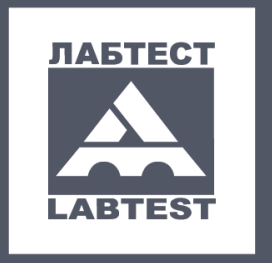

ЭАЕМЕНТНЫЙ И МОАЕКУАЯРНЫЙ АНААИЗ

СВОЙСТВА МАТЕРИААОВ

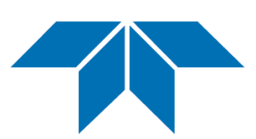

TELEDYNE LEEMAN LABS

Everywhereyoulook

- Аинейка атомно-эмиссионных

спектрометров С инАуктивно-Связанной

п^азмой (ИСП-АЭС) с матричным

Аетектором высокого разрешения; осевого,
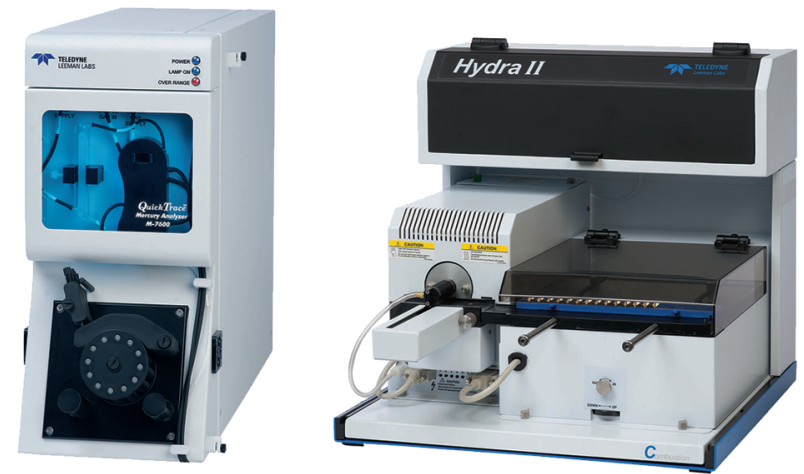

ралиального и Авойного наблюАения п^азмы

- Спектрометры, совмещённые с перчаточными боксами

- Атомно-эмиссионные спектрометры с Аугой постоянного и переменного тока $\Delta \wedge я$ опрелеления ультранизких солержаний примесей от 0,01г/т

- Аинейка автоматических анализаторов ртути А^я жиАКих и твёрАых проб. Пределы обнаружения от 0,1 нг/А в жиАКой пробе и 5 нг/Кг в твёрАой пробе

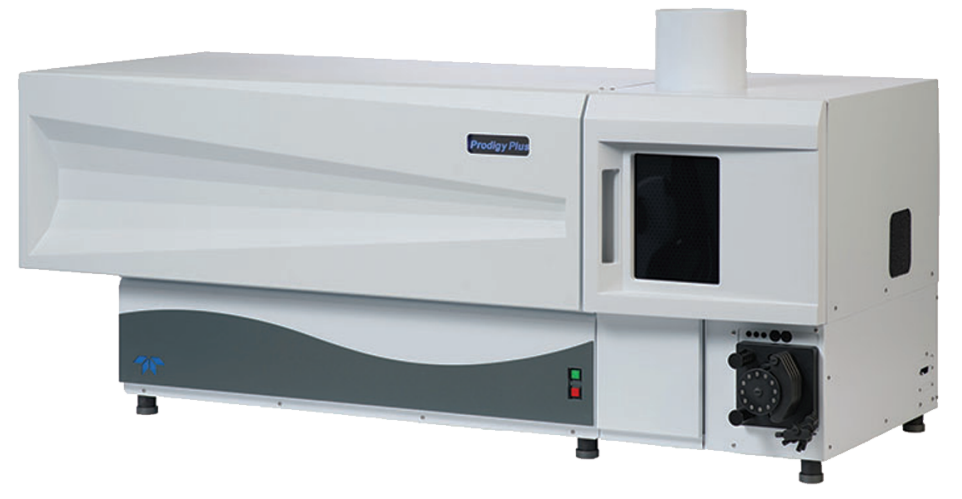

Prodigy Plus • Prodigy7 • GloveBox ICP • Prodigy DCA • M-7600 • M-8000 • Hydra II AA/C
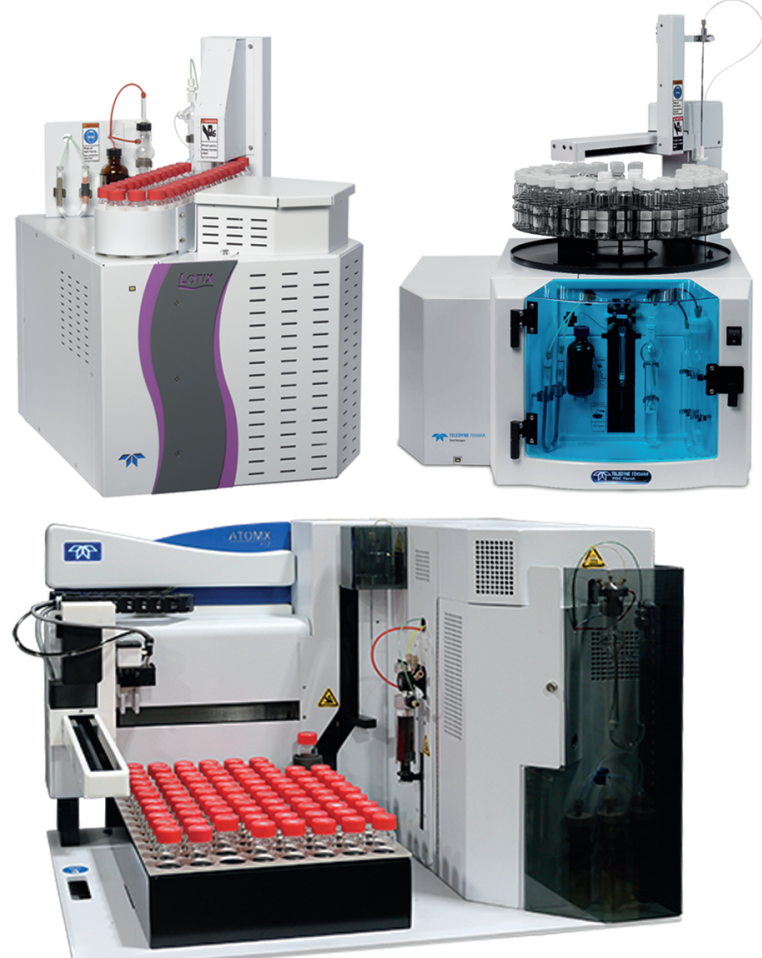

TELEDYNE TEKMAR

- Анализаторы содержания общего органического углерола (TOC)

- Анализаторы солержания общего органического углерода и азота

- Системы автоматизированной пробопоАготовки (purge and trap) А^я опрелеления ^етучих органических соеАинений (VOC) с помощью GC/GC-MS

- Статические и Аинамические системы парофразного анализа (head space) VOC и пробоотбора

- Системы автоматической подготовки проб Аля опреАеления полулетучих органических соеАинений SVOC 


\section{ЦЕНТР ИНТЕЛЛЕКТУАЛЬНОЙ СОБСТВЕННОСТИ "СКОЛКОВО"}

ЦИС "Сколково" ориентирован на оказание услуг резидентам Фонда "Сколково" собственными силами. Резидентам Фонда предоставляются следующие услуги на льготных финансовых условиях:

- nameнmование изобретений (российскал, евразийская или международная РСТ заявка);

- регистращия программ для ЭВМ в России и США;

- регистрация товарного знака (российская и международная заявка);

- проверка патентной чистоты и разработка nатентных ландщафтов;

- зарубежное патентование.

так, стоимость услуг nо подгоmовке u nодаче заявки на получение патента, стоимость услуг nо регистрации товарного знака и стоимость услуг nо регистращии программы для ЭВМ/базы данных для резидентов Фонда "Сколково" составляет
999 руб. Дия сравнения, рыночные цены на подобные услуги составляют: для заявки на изобреmение - от 35 mысяч рублей, для заявки на товарный знак - от 15 mысяч рублей, дяя регистрации программы для ЭВМ - от 10 тысяч рублей.

Кроме того, для оформления зарубежных патенмов резиденты Фонда "Сколково" могут получить микрогрант в размере до 1,5 млн рублей, который позволит компенсировать затраты на оплату пошичн в зарубежных патентных ведомствах, услуг зарубежных nатентных поверенных и юристов, услуг no переводу материалов заявки на иностранные языкu

За 2014-2017 годы через ЦИС "Сколково" было подано более 1500 заявок на регистрацию объекmов интелпектуальной собственности. В 2016 году 12\% международных заявок РСТ, поданных российскими заявителями, были подготовлены и поданы nатентными поверенными ЦИС "Сколково" [5]. конкурентов и, в случае ненадлежащего оформления этих прав, к серьезным издержкам, а для стартап-компаний - даже к полному прекращению деятельности.

К сожалению, в настоящее время российские заявители проявляют крайне низкую активность при патентовании своих изобретений за рубежом. Так, по данным Всемирной организации интеллектуальной собственности, в 2016 году российскими организациями и физическими лицами было подано всего лишь 996 международных заявок (23-е место в мире). Это менее 4\% количества национальных заявок, поданных в Роспатент. Количество поданных в национальные и региональные зарубежные ведомства в этом же году заявок (по данным 25 ведущих ведомств) - 2143. По этому показателю Российская Федерация занимает 22-е место в мире [3].

Низкая патентная активность за рубежом напрямую связана с удручающими экономическими показателями использования результатов интеллектуальной деятельности на внешних рынках. По данным Всемирного банка, в 2016 году по экспорту высокотехнологичной продукции (то есть продукции, в состав которой входят объекты интеллектуальной собственности) Российская Федерация находится на 28-м месте в мире (табл.1), а по полученным платежам за использование объектов интеллектуальной собственности - на 25-м месте (табл.2). И здесь главное даже не само место, а существующее гигантское отставание от стран-лидеров по объему экс- порта и суммам полученных платежей. К примеру, доля России в мировом объеме полученных платежей за использование объектов интеллектуальной собственности составляет всего лишь 0,16\%. Для сравнения - у стран-лидеров эта доля составляет: у США - 37,4\%, у Японии - 11,7\% [4].

Для выявления причин, препятствующих более активному патентованию и использованию результатов интеллектуальной деятельности на внешних рынках, в 2015 году Министерство экономического развития РФ и Фонд национального интеллектуального развития провели опрос среди малых и средних компаний, государственных корпораций и институтов развития. По итогам опроса в качестве двух основных причин были указаны высокие расходы на патентование за рубежом и недостаток доступных консультационных услуг по стратегии правовой охраны и коммерциализации РИД.

Не имея достаточных знаний и средств для обеспечения правовой охраны своих РИД за рубежом, многие российские компании начинают экспортную деятельность без правовой охраны соответствующих изобретений, полезных моделей, промышленных образцов на внешних рынках, что может привести и приводит:

- к утрате исключительных прав российских экспортеров на свою продукцию на зарубежных рынках;

- возможности законного использования/копирования технологии/продуктов третьими лицами, а следовательно: 


\section{АО "РОССИЙСКИЙ ЭКСПОРТНЫЙ ЦЕНТР"}

РЭЦ предоставляет возможность ююбой компании, планирующей экспортную деятельность, бесплатно получить квалифицированные консультации по широкому спектру вопросов в области интеллектуальной собственности. Эксперты РЭЦ:

- проведут анализ текущей ситуации с объектами интеллектуальной собственности, принадлежащими компании и (или) используемыми компанией в своей деятельности;

- подготовят рекомендации по патентно-правовой охране собственных разработок компании;

- информируют о возможных процедурах правовой охраны объектов патентных прав и товарных знаков за рубежом (национальной, региональной, международной); о преимуществах и недостатках каждой процедуры;

- предложат рекомендации по выбору процедуры правовой охраны на основании информации о зарегистрированных товарных знаках, объектов патентных прав и странах предполагаемого экспорта продукции/технологии;

- предостават перечень необходимых документов и порядок действий при регистрации объектах патентных прав и товарных знаков за рубежом в рамках выбранной процедуры;

- проведуm расчет ориентировочных затрат на регистрацию объектов патентных прав и товарных знаков за рубежом;

- помогут в подготовке ициензионного соглашения с зарубежными партнерами.

Дополнительно аккредитованными партнерами

рЭЦ оказываются следующие услуги по вопросам интелпектуальной собственности:

- оформление, подача и ведение делопроизводства по заявкам на регистрацию объектов интеллектуальной собственности, поданным в роспатент и зарубежные национальные и региональные патентные ведомства;

- проведение патентных исследований, включая оценку патентоспособности, патентно-информационный поиск, фирменный и именной патент- ный поиск, разработку патентного ландшафта, исследование патентной чистоты;

- оценка исключительных прав на РИД, бухгалтерский и налоговый учет исключительных прав на РИД в качестве нематериальных активов (НMA); выработка рекомендаций по увеличению стоимости компании за счет формирования, рыночной оценки и корректного отражения НМА на балансе компании;

- юридические услуги:

оформление и регистрация пищензионных договоров и договоров отчуждения искиючительного права на РИД;

оформление в качестве РИД секретов производcmвa (Hoy-хау);

разработка и внедрение в компании системы управления интеллектуальной собственностью;

представление интересов компании в Палате по патентным спорам, судах общей юрисдикции и в Суде по интеллектуальным правам.

С декабря 2016 года АО "Российский экспортный центр" реализует программу компенсаций российским производителям затрат, связанных с регистрацией на внешних рынках объектов интелпектуальной собственности в соответствии с утвержденным постановлением Правительства РФ №7368

На сайте Российского экспортного центра экспортеры могут ознакомиться с руководствами по интеллектуальной собственности для бизнеса:

- "Изобретал будущее". Введение в тему "Патенты для малых и средних предприятий";

- "Создание знака". Введение в тему "Товарные знаки дяя малых и средних предприятий";

- "Стремление к совершенству". Введение в тему "Промышленные образцы дяя малых и средних предприятий".

Информация, содержащаяся в этих руководствах, будет полезна не только начинающим, но и опытным бизнесменам, поскольку адаптирована к новейшему российскому законодательству и насыщена примерами из практики [6].
- падению доходов российских экспортеров и уменьшению их доли на зарубежных рынках.

Еще одним распространенным заблуждением российских экспортеров является уверенность в том, что наличие российского патента обеспечит защиту их продукции/технологии на внешних рынках. Планируя экспорт продукции или технологии, необходимо помнить, что патент на изобретение, полезную модель или промыш- ленный образец имеет территориальное действие, то есть патент Российской Федерации действует только на территории Российской Федерации. Если не получен патент, действующий в стране экспорта, то объекты патентных прав в этой стране охраняться не будут. А это означает, что любое юридическое или физическое лицо в данной стране может без каких-либо ограничений производить, использовать, ввозить или продавать продукцию, соз- 
Таблица 3. Средняя стоимость патентования в зарубежных странах, в доляарах США [7].

\begin{tabular}{|l|c|c|}
\hline \multicolumn{1}{|c|}{ Страна/Ведомство } & $\begin{array}{c}\text { Подача и рассмотрение заяви, } \\
\text { включая услуги патентного } \\
\text { поверенного }\end{array}$ & $\begin{array}{c}\text { Сопровождение в течение } \\
8 \text { лет, включая услуги } \\
\text { патентного поверенного }\end{array}$ \\
\hline США & 7800 & 6600 \\
\hline $\begin{array}{l}\text { Европейское патентное } \\
\text { ведомство }\end{array}$ & 22200 & 26600 \\
\hline Китай & 5400 & 2400 \\
\hline Япония & 6800 & 2200 \\
\hline Республика Корея & 4800 & 2000 \\
\hline
\end{tabular}

данную на основе этого изобретения, без выплаты вознаграждения российскому патентообладателю.

В настоящее время, К сожалению, самостоятельно решить все вопросы, связанные с правовой охраной за рубежом объектов интеллектуальной собственности, не в состоянии не только вузы, научные организации и стартап-компании, но и, зачастую, представители крупного бизнеса и даже государственные корпорации. Среди организаций, оказывающих системную поддержку российским компаниям по вопросам правовой охраны объектов интеллектуальной собственности за рубежом, можно выделить ООО "Центр интеллектуальной собственности "Сколково" и АО "Российский экспортный центр".

Самым серьезным препятствием на пути зарубежного патентования является высокая стоимость затрат на оплату патентных пошлин и услуг зарубежных патентных поверенных. Средняя стоимость расходов на патентование за рубежом и поддержание патентов в силе в странах с максимальной активностью российских заявителей приведена в таблице 3.

Из приведенной таблицы видно, что первоначальные затраты на патентование одного объекта интеллектуальной собственности в странах патентной триады (США, Европейское патентное ведомство, Япония) и Китае составляют порядка 40 тысяч долларов США. Для высокотехнологичных компаний, владеющих портфелем патентов, общие расходы, необходимые для защиты своей продукции/технологии за рубежом, составляют сотни тысяч долларов, что является неподъемной суммой не только для малых, но и для средних компаний.

Таблица 4. Компенсации затрат, связанных с регистрацией на внешних рынках объектов интелпектуальной собственности.

\begin{tabular}{|c|c|c|}
\hline \multirow[b]{2}{*}{ Тип заявки } & \multicolumn{2}{|c|}{ Размер компенсации } \\
\hline & Оплата пошлин & $\begin{array}{c}\text { Оплата услуг по подготовке, } \\
\text { подаче и делопроизводству } \\
\text { по заявкам }\end{array}$ \\
\hline Международная заявка (РСТ) & $100 \%$ & $70 \%$ \\
\hline $\begin{array}{l}\text { Заявка в национальное/ региональное зарубежное па- } \\
\text { тентное ведомство (изобретение, полезная модель, про- } \\
\text { мышленный образец, товарный знак) }\end{array}$ & $100 \%$ & $70 \%$ \\
\hline $\begin{array}{l}\text { Заявка на международную регистрацию товарного знака } \\
\text { в соответствии с Мадридским соглашением/Протоколом } \\
\text { к Мадридскому соглашению }\end{array}$ & $100 \%$ & $70 \%$ \\
\hline
\end{tabular}


Сегодня программы компенсации затрат на зарубежное патентование действуют во многих как европейских, так и азиатских странах, например, в Германии, Ирландии, Финляндии, Эстонии, Беларуси, Сингапуре, Гонконге [8]. С учетом анализа зарубежного опыта с декабря 2016 года АО "Российский экспортный центр" реализует программу компенсаций российским производителям затрат, связанных с регистрацией на внешних рынках объектов интеллектуальной собственности [9-10].

Компенсация затрат предоставляется юридическим лицам (вне зависимости от их организационноправовой формы), зарегистрированным на территории Российской Федерации и производящим товары, услуги, работы и технологии, в состав которых входят объекты интеллектуальной собственности. Организация, претендующая на получение субсидии, должна удовлетворять следующим требованиям:

- не должна получать субсидии из бюджетов бюджетной системы РФ на возмещение одних и тех же затрат, связанных с регистрацией на внешних рынках одних и тех же объектов интеллектуальной собственности;

- не должна иметь задолженности по уплате налогов, сборов, страховых взносов, пеней, штрафов, процентов, подлежащих уплате в соответствии с законодательством Российской Федерации о налогах и сборах;

- доля участия иностранных юридических лиц в уставном (складочном) капитале организации не должна превышать 50\%, если местом регистрации этих лиц является государство или территория, включенные в утверждаемый Министерством финансов РФ перечень государств и территорий, предоставляющих льготный налоговый режим налогообложения и (или) не предусматривающих раскрытия и предоставления информации при проведении финансовых операций (офшорные зоны).

компенсации подлежат фактические затраты, понесенные организациями, в текущем финансовом году и в 4-м квартале предыдущего года. Типы затрат и размеры компенсаций приведены в таблице 4.

В 2017 году было одобрено 126 заявок от 115 организаций на общую сумму 150 млн руб. Более половины одобренных заявок (65) поступило от субъектов малого и среднего предпринимательства. Компенсированы затраты на регистрацию за рубежом 770 объектов интеллектуальной собственности, из них:

- международные заявки (РСТ) - 64;

- заявки в национальные/региональные патентные ведомства - 480;
- заявки на международную регистрацию товарных знаков - 226.

Во многом благодаря действию программы в 2017 году увеличилось количество зарубежных заявок от российских заявителей:

- международных заявок РСТ - на 22,7\%;

- заявок на международную регистрацию товарных знаков - на 23,9\% [11].

Программа продолжает свое действие и в 2018 году и позволяет сделать зарубежное патентование доступным не только для крупных компаний, но и для малого бизнеса, в том числе для высокотехнологичных стартап-компаний, а также для вузов и научных организаций.

\section{ЛИТЕРАТУРА}

1. Гражданский кодекс Российской Федерации, ст. 1395.

2. Изобретая будущее. Введение в тему "Патенты для малых и средних предприятий". Серия "Интеллектуальная собственность для бизнеса". №3. М., 2017. 86 с.

3. Официальный сайт Всемирной организации интеллектуальной собственности - http://www.wipo.int/ edocs/pubdocs/en/wipo_pub_941_2017.pdf.

4. Официальный сайт Всемирного банка - http://data. worldbank.org/indicator.

5. Официальный сайт ООО "Центр интеллектуальной собственности "Сколково" - http://sk.ru/foundation/ipcenter/

6. Официальный сайт АО "Российский экспортный центр" - https://www.exportcenter.ru/services/sertifikatsiya-i-litsenzirovanie/patentovanie/.

7. Официальный сайт ФГБу "Федеральный институт промышленной собственности" - http://wwwl.fips.ru/ wps/wcm/connect/content_ru/ru/fonds/vstr_190116

8. Концепция создания и функционирования патентного фонда, Российская венчурная компания. М., 2015. 55 с.

9. Постановление Правительства Российской Федерации от 15 декабря 2016 г. №1368 "О предоставлении субсидий российским производителям на финансирование части затрат, связанных с регистрацией на внешних рынках объектов интеллектуальной собственности".

10. Постановление Правительства Российской Федерации от 02 декабря 2017 г. №1459 "О внесении изменений в Правила предоставления субсидий российским производителям на финансирование части затрат, связанных с регистрацией на внешних рынках объектов интеллектуальной собственности".

11. Официальный сайт Всемирной организации интеллектуальной собственности - http://www. wipo.int/ipstats/en/statistics/country_profile/profile. jsp?code=RU 


\section{PBWER M ElEETIRONICS}

15-я Международная выставка компонентов и систем

силовой электроники

\section{3-25 октября 2018}

Москва, Крокус Экспо

\section{Силовая «uff כлектроника}

Единственная в России

специализированная

выставка компонентов

и систем силовой электроники для различных отраслей промышленности

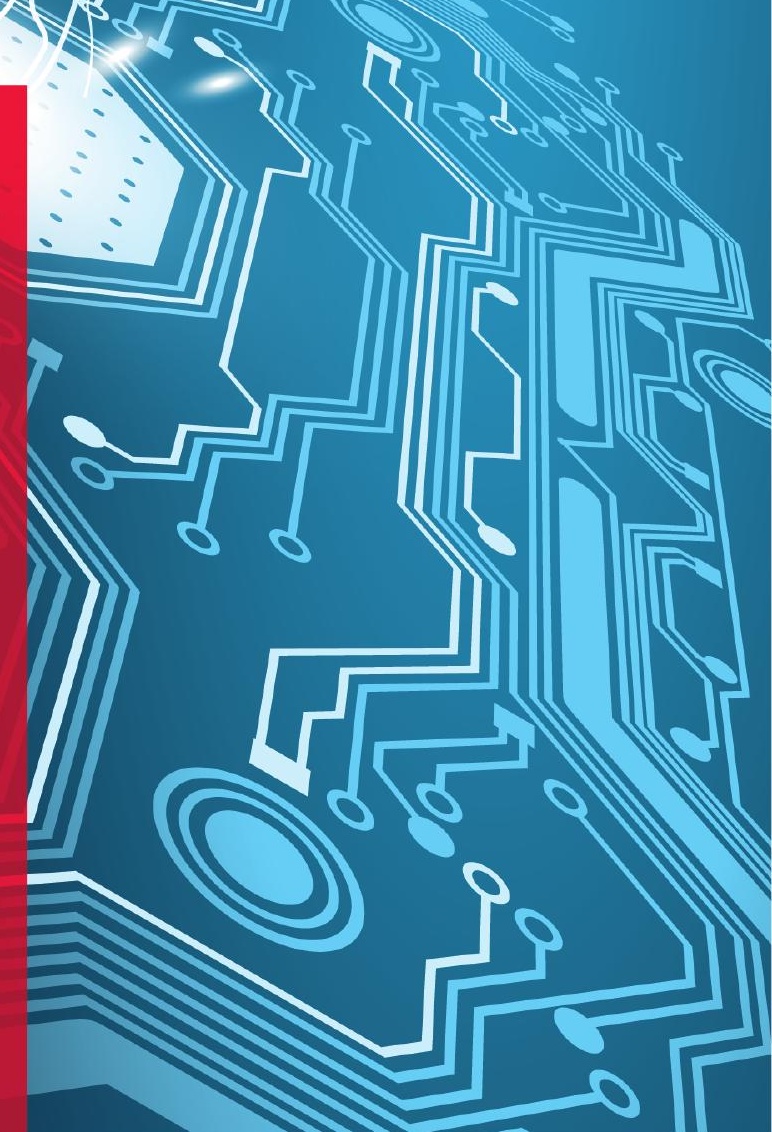

Подробнее о выставке powerelectronics.ru 